\title{
JURNAAL

\section{Pengaruh Marketing Media Sosial Instagram Terhadap Brand Image The Bunker Café, Tangerang}

\author{
(The Influence of Instagram Social Media Marketing on The Brand Image of \\ The Bunker Café, Tangerang)
}

\author{
Tri Djoko Sulistiyo ${ }^{1}$, Rina Fitriana ${ }^{2}$, Catherina Lee ${ }^{3}$ \\ ${ }^{1}$ Sekolah Tinggi Pariwisata Trisakti ${ }^{2}$ Politeknik Sahid, \\ rinafitriana@polteksahid.ac.id
}

\begin{tabular}{l}
\hline Info Artikel (11 pt) \\
\hline Diterima Agustus 1, 2020 \\
Direvisi Agustus 20, 2020 \\
Dipubikasi September 20, \\
2020 \\
\end{tabular}

Kata Kunci:

Brand Image, Café, Instagram, Pemasaran, Sosial Media

\begin{abstract}
Abstrak
Penelitian ini dilakukan untuk mengetahui penggunaan media sosial marketing Instagram pada The Bunker Café, tanggapan konsumen terhadap pembentukan Brand Image pada The Bunker Café, dan seberapa besar pengaruh antara media sosial marketing Instagram terhadap pembentukan brand image pada The Bunker Café di Gading Serpong, Tangerang. Penelitian ini menggunakan metode penelitian deskriptif kuantitatif. Pengumpulan data dalam bentuk kuesioner, dengan berjumlah 100 responden sesuai dengan rumus Slovin yang digunakan untuk mengetahui besaran sampel. Metode analisis yang digunakan adalah uji statistik deskriptif, uji validitas, uji reliabilitas data, koefisien determinasi, uji regresi linear sederhana, dan uji hipotesis yang diolah menggunakan program Statistical Package for Social Sciences (SPSS) versi 26.0 for Mac. Hasil penelitian menunjukkan bahwa mean dari media sosial marketing Instagram adalah 2,94. Maka dapat diartikan bahwa media sosial marketing Instagram The Bunker Café tergolong menarik dan The Bunker Café menjadikan media sosial marketing Instagram menjadi media komunikasi yang interaktif dengan konsumennya. Mean dari Brand Image adalah 3,40. Maka dapat diartikan bahwa Brand Image The Bunker Café tergolong sangat baik. Berdasarkan hasil analisis dapat diketahui bahwa media sosial marketing Instagram mempunyai pengaruh sebesar $19,1 \%$ terhadap pembentukan Brand Image pada The Bunker Café di Gading Serpong, Tangerang. Sedangkan sisanya yaitu
\end{abstract}


Keywords : Brand Image;

Café; Instagram; Social

Media, Marketing
$80,9 \%$ dipengaruhi oleh faktor lain yang tidak diteliti dalam penelitian ini

\section{PENDAHULUAN}

\begin{abstract}
This research was conducted to determine the use of social media marketing Instagram at The Bunker Café, consumers' response to the establishment of brand image in The Bunker Café, and how much influence between social media marketing Instagram to the establishment of brand image in The Bunker Café in Gading Serpong, Tangerang. This research uses quantitative descriptive research methods. Collection of data in the form of questionnaires, amounting to 100 respondents in accordance with the formula Slovin used to know the size of samples. The analytical methods used are descriptive statistical tests, validity tests, data reliability tests, coefficient of determination, simple linear regression tests, and hypothesized testing using the Statistical Package for Social Sciences (SPSS) program version 26.0 for MAC. The results showed that the mean of social media marketing Instagram was 2.94. Then it can be interpreted that social media marketing Instagram The Bunker Café is interesting and The Bunker Café makes social media marketing Instagram a medium of communication with consumers. The Mean of Brand Image is 3.40. Then it can be interpreted that The Brand Image of The Bunker Café is very good. Based on the results of the analysis can be known that social media marketing Instagram has an influence of $19.1 \%$ against The establishment of Brand Image in The Bunker Café in Gading Serpong, Tangerang. The remaining $80.9 \%$ is influenced by other factors not examined in this study.
\end{abstract}

Dewasa ini, teknologi dan informasi berkembang semakin pesat seiring perkembangan zaman pada era globalisasi ini. Pengguna internet di dunia dari hari ke hari mengalami perkembangan yang cukup pesat. Riset Nielsen menunjukkan tingkat pertumbuhan penggunaan internet di Indonesia mencapai $26 \%$. Begitu pula menurut Lesmana (2012), orang Indonesia mengalokasi 1,5 jam dalam sehari untuk menggunakan internet, baik dengan tujuan hiburan maupun bisnis. 
Banyak pemakai internet di Indonesia yang menggunakannya untuk berdagang sehingga industri pun menjadi lebih berkembang berkat kehadiran internet. Salah satu jenis pemanfaatan teknologi internet adalah melalui sosial media, dimana sosial media ini merupakan saluran yang banyak digunakan oleh produsen untuk memasarkan produknya. Berbagai produk dapat ditemukan melalui sosial media, mulai dari pakaian, kosmetik, sampai pada restoran dan makanan serta minuman yang termasuk ke dalam industri kuliner.

Marketing pada dewasa ini sudah jauh lebih maju sesuai dengan perkembangan yang terjadi dalam teknologi. Hal ini memudahkan konsumen untuk mencari jenis produk yang dibutuhkan, serta untuk terkoneksi baik dengan produsen smaupun dengan sesama konsumen lainnya. Konsekuensi dari keterbukaan semacam itu adalah meningkatnya persaingan diantara produk, dimana informasi mengenai suatu produk dapat terbuka dibahas oleh sesama konsumennya di berbagai belahan dunia, sehingga mendorong produsen agar selalu menjaga dan meningkat kualitas produk untuk dapat mempertahankan konsumennya agar tidak tergoda mencoba serta berpaling ke produk lain yang sejenis. Salah satu media sosial yang sudah terkenal dala membantu marketing adalah Instagram.

Melakukan pemasaran melalui Instagram telah menjadi salah satu dalam strategi yang diterapkan oleh masing-masing pelaku bisnis dalam melariskan produk dan atau jasanya. Pelaku bisnis dapat melihat hal ini sebagai peluang kegiatan yang positif dalam membangun brand image dalam usahanya. Mereka menyadari bahwa target konsumen yang dibidik lebih banyak berasal dari media sosial yaitu Instagram. Selain karena tingkat penggunaan Instagram yang tinggi, biaya yang dikeluarkan sangat sedikit dibandingkan dengan sistem pemasaran offline. Efektivitas dan efisiensi ini yang kemudian membuat Instagram menjadi salah satu alat pemasaran yang banyak dipilih oleh produsen barang/jasa untuk pembentukan brand image yang baik bagi produk yang dihasilkannya.

Sementara itu, perkembangan dunia industri kuliner di Indonesia berbanding lurus dengan persaingan di dalamnya. Semakin banyaknya bisnis kuliner yang dibuka, menyebabkan pemain dalam pasar kuliner juga bertambah sehingga berimbas pada 
ketatnya persaingan yang terjadi di dunia industry kuliner. Untuk itu para pemilik bisnis kuliner harus terus berinovasi untuk dapat bertahan dalam pasar yang semakin ketat. Inovasi ini dilakukan dalam pengembangan produk, pelayanan maupun pemasaran yang didalamnya meliputi promosi dan cara penjualan yang unik sehingga menjadi suatu kekhasan produk tersebut. Sebagai salah satu contoh, beberapa tahun lalu kita melihat bagaimana kripik pedas Ma Icih melakukan teknik pemasaran yang berbeda melalui penjualannya di twitter, dimana teknik penjualan ini berhasil menyedot minat konsumen dari kalangan muda. Pemasaran produk Ma Icih pun pada saat itu menyebabkannya memiliki brand image yang kuat sebagai jajanan kekinian, walaupun produk yang dijual sebenarnya merupakan produk jadul, yaitu kripik singkong.

Membangun brand image yang kuat tidak hanya melalui komunikasi atau promosi, tetapi juga tetap pada hal utama yaitu kinerja karyawan kualitas produk, pelayanan yang memuaskan, kredibilitas perusahaan yang terpercaya. Dengan demikian perusahaan harus menjaga dan mengelola brand sedemikian rupa agar memperoleh posisi terbaik dalam benak masyarakat. Perkembangan zaman, yang ditandai dengan semakin majunya teknologi, menuntut semua lapisan masyarakat untuk terus berinovasi, salah satunya dalam bidang industri kuliner yang diminati oleh seluruh masyarakat Indonesia.

Kuliner tidak lagi identik dengan kebutuhan fisiologis semata akan tetapi sudah erat kaitannya dengan gaya hidup sehingga pertumbuhan industri kuliner pun menjadi sangat pesat. Dalam hal Badan Pusat Statistik (BPS) menyatakan ahwa pertumbuhannya pada tahun 2013 mencapai angka 13,1 dan berarti telah mengalami pertumbuhan dibandingkan dengan peetumbuhannya pada 2012 yang hanya mencapai angka $8 \%$.

Industri kuliner di Indonesia juga bertambah kaya dalam hal varian, dimana makanan saat ini bukan saja dipersoalkan dari segi rasa akan tetapi juga dari segi kemasannya yang dibentuk untuk menjadi secantik dan seartistik mungkin. Untuk itu pulalah media social menjadi ajang bagi pemasaran kuliner, dan salah satu media sosial ini adalah Instagram. Dalam jagad media sosial, saat ini kita mengenal instagrammable, yaitu sebuah istilah khusus untuk menyebut foto-foto yang menarik, unik dan cantik yang kemudian diunggah ke media sosial. 
Salah satu tempat yang sangat diminati berbagai kalangan masyarakat adalah sebuah café. Banyak sekali café yang terdapat di berbagai lokasi, pada umumnya café merupakan tempat untuk bersantai yang biasanya ditemani dengan secangkir kopi. Berbagai brand pun telah banyak dikenal masyarakat, namun masih sedikit café yang tergolong memiliki konsep yang unik dan memiliki personalitas sendiri.

The Bunker Café adalah sebuah café yang didirikan pada 28 November 2015, dengan konsep unik café yang tidak pada umumnya. The Bunker Café menawarkan pengunjungnya untuk dapat bermain board games sambil menikmati hidangan yang disediakan sesuai pesanan konsumen. Hal ini menjadi keunggulan The Bunker Café yang banyak diminati masyarakat luas karena keunikannya yang berbeda dari café pada umumnya. Banyak masyarakat luas yang tertarik untuk bermain board games yang beragam, sekitar 400 variasi board games yang disediakan oleh The Bunker Café.

Dengan tujuan mengimbangi perkembangan persaingan bisnis di era globalisasi ini, The Bunker Café juga memutuskan untuk menggunakan Instagram sebagai salah satu strategi pemasarannya atau dapat disebut media sosial marketing. Dengan menggunakan media sosial Instagram sebagai media pemasaran, secara tidak langsung The Bunker Café juga membangun brand image mereka sendiri dimata para konsumennya, karena media Instagram yang kekinian identik dengan pangsa pasar kaum milenial sehingga hal ini seolah menegaskan bahwa sasaran konsumen yang akan dituju oleh café tersebut adalah generasi muda.

\section{Media Sosial}

Kaplan dan Haenlein (2010) berpendapat bahwa media sosial adalah sebuah kelompok aplikasi berbasis internet berlandasakan ideologi dan teknologi web 2.0 serta memungkinkan penciptaan dan pertukaran user-generated content atau konten yang dioperasikan oleh penggunanya. Kotler dan Keller (2012) menganggap sebuah media sosial adalah ajang bagi konsumen untuk berbagi informasi yang berupa teks maupun gambar atau video yang berhubungan suatu produk baik diantara sesamanya maupun antara konsumen dengan perusahaan/produsen.

Dengan demikian media sosial dapat dikatakan merupakan wadah dan sarana komunikasi bagi konsumen maupun perusahaan untuk bertukar informasi dan tanggapan 
mengenai pemasaran dan pemakaian suatu produk/jasa.

\section{Media Sosial Marketing}

"Marketing 4.0 adalah pendekatan pemasaran yang mengombinasikan interaksi online dan offline antara perusahaan dan konsumen, membangun gaya dengan substansi dalam membangun merek, dan akhirnya melengkapi sambungan antar mesin dengan antar manusia untuk memperkuat customer engagement” (Kotler; 2016:53). Kim and Ko (2011) memasukkan aktivitas di media social sebagai bagian dari hiburan, gaya hidup dan promosi produk yang berbentuk word of mouth communication. Kegiatan pemasaran media sosial adalah sebuah cara pemasaran yang menggabungkan interaksi online dengan keterlibatan individu di dalam masyarakat yang bertujuan untuk membentuk sebuah pasar di dunia maya. Kegiatan pemasaran yang terjadi di dalamnya dapat berupa produksi, promosi, penjualan dan distribusi produk/jasa dari satu pihak ke pihak yang lain yang menjadi gaya hidup, entertaiment, penyesuaian terhadap teknologi dan komunikasi saat ini. Proses pemasaran ini juga di dalamnya melibatkan pertukaran informasi mengenai suatu produk dan pemberian tanggapan serta pengalaman terhadap suatu produk.

Media sosial marketing menurut Salvatore (2005) merupakan pasar dalam dunia maya yang dibentuk dari keterlibatan masyarakat dalam kegiatan pemasaran yang dilakukan online. Media sosial marketing melibatkan komunikasi interaktif (dua arah) diantara produsen dan konsumen secara online yang mempengaruhi kesadaran, memperbaiki citra, maupun menciptakan suatu produk, baik berbentuk barang maupun jasa, yang dapat dijual pada masyarakat (Kotler \& Keller, 2009).

Media sosial marketing yang merupakan tambahan terbaru dalam kegiatan pemasaran khususnya digunakan sebagai wadah bagi komunikasi pemasaran terpadu. Komunikasi terpadu adalah prinsip organisasi (dalam hal ini produsen) yang terhubung dengan pasar sasaran mereka (konsumen) dimana kegiatannya meliputi promosi penjualan, hubungan masyarakat, periklanan, dan lain sebagainya. (Mangold dan Faulds, 2009).

Selain itu, pemasaran di sosial media juga tidak saja dilakukan oleh produsen akan 
tetapi juga dapat dilakukan oleh konsumen yang loyal dan membuat review tentang suatu produk yang biasanya dimuat dalam blog/vlog. Fitriana dkk (2020) menemukan bahwa online review yang merupakan salah bentuk ewom merupakan cara yang lebih efektif dalam menarik calon konsumen dibanding iklan konvensional. Pemasaran media sosial menurut Gunelius (2010) memiliki beberapa tujuan umum yang meliputi:

1.Membangun komunikasi aktif dengan konsumen, yang didalamnya meliputi tanggapan, kritikan serta saran akan suatu produk.

2.Membangun dan meningkatkan merek serta brand awareness pada konsumen.

3.Sebagai media untuk berbagi informasi dan memodifikasi persepsi negatif konsumen agar menjadi sebuah persepsi yang positif.

4.Promosi dalam bentuk diskon eksklusif dengan maksud memberikan apresiasi kepada konsumen dan demi memenuhi tujuan jangka pendek marketing yaitu untuk meningkatkan angka penjualan

5.Riset pasar yang akan berguna untuk melihat tanggapan para konsumen terhadap produk yang telah dipasarkan, serta mempelajari lebih jauh mengenai karakteristik konsumen dari produk yang dipasarkan tersebut serta para pesaing yang ada di pasar produk tersebut.

\section{Variabel Media Sosial Marketing}

Shojaee dan Azman (2013) berpendapat bahwa terdapat 3 (tiga) variabel pemasaran media sosial yang didalamnya meliputi:

\section{Brand Exposure}

Gole (2009) dalam Shojaee dan Azman melihat brand exposure sebagai strategi yang dirancang perusahaan dalam menciptakan sebuah brand awareness bagi produk yang mereka jual. Penjelasan di atas dapat diartikan sebagai strategi sebuah perusahaan untuk memasarkan brand atau merek perusahaan tersebut untuk mencapai kesadaran konsumen sehingga diakui dan dikenal oleh masyarakat umum, seperti content marketing pada media sosial perusahaan tersebut, logo perusahaan, advertising, sponsorship, influencer marketing, dan strategi-strategi lainnya.

\section{Customer Engagement}

Hans William (2011) berpendapat bahwa customer engagement merupakan 
kesempatan yang diberikan produsen kepada konsumen agar dapat berkomunikasi dan terlibat dalam dialog interaktif mengenai pengalaman pribadi konsumen mengenai produk yang dicapakai. Keterlibatan konsumen (customer engagement) merupakan suatu syarat bagi tercipatnya loyalitas konsumen, komitmen, koneksi, pemberdayaan dan kepuasan konsumen.

\section{Electronic Word of Mouth (eWOM)}

Henning-Thurau (2004) menyatakan bahwa electronic word of mouth adalah tanggapan konsumen yang diberikan melalui dunia maya (cyberspace), baik bermuatan positif maupun negatif, yang disebarkan dari satu konsumen kepada konsumen maupun calon konsumen lainnya, dimana tindakan ini dilakukan atas dasar sukarela dan bukan merupakan promosi yang dibiayai oleh perusahaan serta merupakan suatu bentuk ekspresi kesukaan/ketidaksukaan terhadap pengalaman mengkonsumsi suatu produk/jasa. Bisa disimpulkan bahwa eWOM adalah bentuk sebuah komunikasi pemasaran yang bukan merupakan pengaturan produsen akan tetapi murni bersumber dari kepuasan/ketidakpuasan konsumen atas pengalamannya memakai suatu produk tertentu yang kemudian diungkapkannya melalui media komunikasi berbasis online. eWOM membuat komunikasi yang terjadi diantara produsen dan konsumen menjadi lebih cepat dan mudah serta sesuai dengan tren saat ini, seperti yang dapat dilihat pada review dan comment yang dilakukan di media sosial.

\section{Instagram}

Instagram berasal dari kata insta dan gram, yang bisa diartikan sebagai telegram yang instan. Hal ini dikaitkan dengan kemampuannya yang dapat mempublikasikan foto dan video dengan cepat ke seluruh penjuru dunia dengan memanfaatkan jaringan internet, yaitu dengan jalan mengunggah foto atau video tadi ke dalam akun Instagram. Karena kemampuan Instagram untuk menampilkan informasi, media sosial satu ini juga pada perkembangannya seringkali menjadi sebuah wadah promosi bagi produk yang dihasilkan oleh para penggunanya, bahkan penelitian Simply Measured baru-baru ini mengungkapkan sebuah fakta bahwa perusahan ternama yang menggunakan alat pemasaran Instagram adalah sebanyak $54 \%$.

\section{Brand Image (Citra Merek)}


Kotler (2000: 97) mengatakan bahwa brand melebihi sebuah symbol yang menjadi pembeda antara suatu produk dengan produk sejenis lainnya. Lebih dari itu, brand juga menggambarkan janji produsen untuk terus-menerus memberikan feature, manfaat dan jasa tertentu kepada konsumen.

Kemudian Aaker dalam Ritonga (2011) mengatakan bahwa brand image adalah keputusan asosiasi brand yang terbentuk dan melekat dibenak konsumen. Sementara Hsieh, Pan dan Setiono (2004), sebuah brand image yang sukses memungkinkan konsumen untuk mengidentifikasi barang/jasa tersebut dengan kepuasan yang berbeda dengan apa yang mungkin didapatkan dari barang sejenis dengan merek yang berbeda, yang kemudian menjadikan produk tersebut dipilih untuk memenuhi kebutuhan dan keinginannya.

Merek-merek produk yang sudah lama ada di pasaran akan mengandung citra atau simbol tertentu yang mengidentifikasikannya dengan status sosial si pamakai. Simamora (2004, dalam Wijaya, 2008) berpendapat bahwa citra merek meliputi 3 (tiga) komponen yaitu citra perusahaan, citra pemakai dan citra produk. Ketiganya memberikan citra positif/negatif terhadap merek tertentu yang diwakili dengan ukuran yang berupa adanya kesan positif di bidangnya, reputasi yang tinggi dan kemudahan dikenali. Citra merek juga dipengaruhi banyak faktor eksternal yang tidak dapat dikendalikan oleh produsen. Salah satu contoh brand image yang sukses adalah produk Apple dengan Iphone nya, dimana penggunaan produk tersebut akan melambangkan kelas sosial tertentu, yaitu kelas sosial masyarakat kelas atas.

\section{Komponen Brand Image}

Plummer (dalam Ratri, 2007) menyatakan bahwa citra merek terdiri atas 3 (tiga) komponen, yaitu:

1. Atribut produk (product attribute) adalah hal yang berhubungan dengan merek dan menjadi pembeda dan menambah nilai suatu produk seperti kemasan, rasa, harga, dan lain-lain.

2. Keuntungan konsumen (consumer benefits), adalah manfaat produk dari merek tersebut, sebagai contoh seberapa besar keuntungan kegunaan produk dari merek tersebut yang dirasakan oleh konsumen. 
3. Kepribadian merek (brand personality), merupakan asosiasi karakter yang terkandung di dalam sebuah merek. Ini terbentuk melalui sikap konsumen terhadap merek tertentu sehingga bersifat simbolik dan menunjukkan ekspresi pribadi si konsumen.

\section{METODE PENELITIAN}

Penelitian ini adalah penelitian menggunakan metode deskriptif kuantitatif yang bermaksud mengetahui nilai dari sebuah variabel mandiri tanpa menghubungkannya dengan variabel lain, untuk kemudian menginterpretasikan nilai tadi ke dalam tulisan sistematis (Sugiyono, 2017). Variable bebas dalam penelitian ini adalah Marketing Media Sosial Instagram sedangkan variabel terikatnya adalah Brand Image. Pendekatan kuantitatif dijalankan melalui pengumpulan data dengan alat kuesioner yang dibagikan kepada 100 responden dari total populasi sebanyak 6000 orang yang merupakan jumlah rata-rata pengunjung café tersebut setiap bulannya.

Sampel ini diambil dengan cara purposive sampling, yaitu menetapkan karakteristik khusus yang dimiliki oleh sampel sehingga cocok dengan tujuan penelitian. Data primer tersebut kemudian diolah dan disajikan dalam bentuk tulisan yang sistematis. Dalam pelitian ini yang dijadikan unit analisisnya adalah konsumen The Bunker Café. Penelitian ini dilakukan selama 3 bulan, dari bulan Oktober 2019 sampai dengan bulan Desember 2019 yang bertempat di The Bunker Café yang beralamat di Ruko Graha Boulevard Blok D No. 10-11 Gading Serpong, Tangerang.

\section{HASIL DAN PEMBAHASAN}

\section{Demografi Responden}

Responden pria sejumlah 43 responden (43\%) dan wanita sejumlah 57 responden (57\%). Dapat disimpulkan bahwa jenis kelamin responden didominasi oleh kaum wanita. Hal ini disebabkan karena lebih banyaknya kaum wanita yang berkunjung dan melihat media sosial marketing Instagram The Bunker Café dibandingkan dengan kaum pria.

Responden berusia 12-20 tahun berjumlah 29 responden (29\%), 21-30 tahun sebanyak 69 responden (69\%), 31-40 tahun terdapat 1 responden (1\%), dan di atas 40 tahun sebanyak 1 responden (1\%). Dapat disimpulkan bahwa usia responden yang berkunjung dan melihat media sosial marketing Instagram The Bunker Café sangat 
beragam dikarenakan konsep café yang cocok untuk segala usia, namun didominasi oleh responden yang berusia 21-30 tahun. Hal ini bisa terjadi karena sarana dan prasarana serta menu yang disediakan oleh café tersebut memang lebih cocok untuk kelompok umur tadi dibandingkan dengan kelompok umut di atas maupun di bawahnya.

Dari 100 responden terlihat bahwa 2 responden (2\%) merupakan pelajar, 82 responden $(82 \%)$ merupakan mahasiswa/i, 5 responden $(5 \%)$ merupakan pegawai negeri atau swasta, 10 responden (10\%) merupakan wirausaha, dan 1 responden (1\%) merupakan seorang ibu rumah tangga. Dapat disimpulkan dari tabel di atas mahasiswa/i yang mendominasi dikarenakan The Bunker Café banyak diminati oleh para mahasiswa/i.

Sejumlah 60 responden (60\%) berkunjung 1 kali dalam sebulan, 16 responden $(16 \%)$ berkunjung 2-3 kali dalam sebulan, 5 responden (5\%) berkunjung 4-5 kali dalam sebulan, dan sejumlah 19 responden (19\%) berkunjung di atas 5 kali dalam sebulan ke The Bunker Café. Dapat disimpulkan bahwa responden dominan berkunjung ke The Bunker Café sebanyak 1 kali dalam kurun waktu satu bulan.

\section{Statistik Deskriptif}

Nilai mean tertinggi variabel $\mathrm{X}$ adalah 3,27 yang terdapat pada pernyataan $\mathrm{X} 4$ "The Bunker Café menjadikan media sosial marketing (Instagram) sebagai media komunikasi yang interaktif dengan konsumennya", hal ini menunjukkan bahwa responden setuju dengan pernyataan tersebut. Sedangkan mean terendah adalah 2,44 yang terdapat pada pernyataan X5 "Saya memberikan ulasan (review) pada The Bunker Café melalui akun Instagram saya", hal ini menunjukkan bahwa responden tidak setuju dengan pernyataan tersebut diakibatkan dari belum banyaknya pengunjung yang aktif untuk memberi ulasan dalam media sosial Instagram mengenai pengalamannya selama di The Bunker Café.

Nilai mean tertinggi variabel Y adalah 3,60 yang terdapat pada pernyataan Y17 "The Bunker Café merupakan tempat untuk bermain board games", hal ini menunjukkan bahwa responden setuju dengan pernyataan tersebut dikarenakan The Bunker Café identik dengan persona café untuk bermain board games. Nilai mean terendah adalah 3,13 yang terdapat pada pernyataan Y12 "The Bunker Café memberi harga yang sesuai dengan produk dan jasa yang diberikan", hal ini menunjukkan bahwa responden juga setuju dengan pernyataan tersebut dikarenakan harga yang diberikan oleh The Bunker Café 
berbanding sejajar terhadap kualitas produk dan jasa yang diberikan kepada pengunjungnya.

\section{Uji Validitas}

Berdasarkan analisis semua data memiliki koefisien validitas lebih besar daripada nilai rtabel yaitu 0,165 sehingga dapat disimpulkan bahwa seluruh pernyataan pada kuesioner tersebut valid. Pernyataan di dalam kuesioner tersebut dapat digunakan dengan baik dalam mengukur variabel media sosial marketing (X).

Semua data memiliki koefisien validitas lebih besar daripada nilai $r$ tabel yaitu 0,165 sehingga disimpulkan bahwa seluruh pernyataan pada kuesioner tersebut valid. Hal ini menunjukkan bahwa pernyataan di dalam kuesioner tersebut dapat digunakan dengan baik untuk mengukur variabel brand image (Y).

\section{Uji Reliabitas}

Cronbach's Alpha variabel X adalah 0,815 > 0,6 atau dapat dikatakan bahwa seluruh pernyataan pada variabel $\mathrm{X}$ bernilai lebih besar dari 0,6. Disimpulkan bahwa seluruh variabel X dinyatakan reliabel. Reliabel berarti terdapat konsistensi dalam jawaban responden ats indikator yang diajukan dalam kuesioner. Hasil nilai Cronbach's Alpha variabel $\mathrm{X}$ adalah sebesar 0,815 yang tergolong memiliki tingkat interpretasi tinggi.

Nilai Cronbach's Alpha variabel Y adalah sebesar 0,864 > 0,6 atau dapat dikatakan bahwa seluruh pernyataan pada variabel Y memiliki nilai koefisien Cronbach's Alpha lebih besar dari 0,6. Disimpulkan bahwa seluruh variabel Y dinyatakan reliabel. Reliabel diartikan bahwa responden berhasil menjawab indikator yang diajukan dengan konsisten. Berdasarkan tabel interpretasi uji reliabilitas, hasil nilai Cronbach's Alpha variabel Y adalah sebesar 0,864 yang tergolong memiliki tingkat interpretasi tinggi.

\section{Regresi Linier Sederhana}

Persamaan regresi linear sederhana antara Media Sosial Marketing (X) terhadap Brand Image (Y) sebagai berikut:

$\mathrm{Y}=21,342+0,353 \mathrm{X}$

Dari persamaan di atas, dapat dijelaskan bahwa jika Media Sosial Marketing (X) bersifat konstan atau tidak mengalami perubahan, maka konstanta Brand Image (Y) 
sebesar 21,342 satuan. Nilai Regresi Media Sosial Marketing (X) sebesar 0,353, dapat disimpulkan bahwa setiap terjadi kenaikan satu satuan penilai responden terhadap Brand Image (Y), maka akan meningkatkan Brand Image (Y) sebesar 0,353. Jika Media Sosial Marketing (X) mengalami peningkatan, maka akan semakin meningkatkan Brand Image (Y) dan sebaliknya.

Koefisien Determinasi

Koefisien determinasi pada penelitian ini adalah $\mathrm{R}$ sebesar 0,191 atau 19,1\%. Maka dapat disimpulkan bahwa media sosial marketing Instagram mempunyai pengaruh sebesar 19,1\% terhadap brand image The Bunker Café dan 80,9\% dipengaruhi oleh beberapa faktor lain yang tidak diikutkan dan dibahas dalam penelitian ini, seperti misalnya harga, kemasan dan lain sebagainya.

\section{Uji Hipotesis (T)}

Uji t dilakukan untuk mengetahui pengaruh antara Media Sosial Marketing (X) terhadap Brand Image (Y) dengan membandingkan nilai thitung dengan ttabel. Jika thitung > ttabel maka dapat dinyatakan Media Sosial Marketing Instagram (X) mempunyai pengaruh terhadap pembentukan Brand Image (Y) pada The Bunker Café di Gading Serpong, Tangerang, dan apabila thitung < ttabel maka dapat dinyatakan Media Sosial Marketing (X) Instagram tidak mempunyai pengaruh terhadap pembentukan Brand Image (Y) pada The Bunker Café di Gading Serpong, Tangerang.

Nilai ttabel pada $\alpha=0,05$ adalah sebesar 1,660. Hal ini menunjukkan bahwa thitung $>$ ttabel (4,816> 1,660) sehingga dapat dinyatakan bahwa Media Sosial Marketing melalui Instagram (X) mempengaruhi pembentukan Brand Image (Y) pada The Bunker Café di Gading Serpong, Tangerang.

\section{KESIMPULAN DAN SARAN}

Berdasarkan hasil analisis statistik deskriptif, mean dari media sosial marketing Instagram adalah 2,94. Maka dapat diartikan bahwa media sosial marketing Instagram The Bunker Café tergolong menarik dan The Bunker Café menjadikan media sosial marketing melalui Instagram menjadi media komunikasi yang interaktif dengan konsumennya.

Hasil analisis statistik deskriptif, mean dari brand image adalah 3,40. Maka dapat 
diartikan bahwa brand image The Bunker Café tergolong sangat baik. Tanggapan konsumen terhadap brand image The Bunker Café adalah tempat untuk bermain board games.

Terdapat pengaruh positif antara media sosial marketing melalui Instagram terhadap pembentukan brand image yaitu sebesar $19,1 \%$. Sedangkan $80,9 \%$ sisanya terdiri dari beberapa faktor lain yang tidak disertakan di dalam penelitian ini. Uji hipotesis menunjukkan bahwa Media Sosial Marketing melalui Instagram (X) mempengaruhi pembentukan Brand Image (Y) pada The Bunker Café di Gading Serpong, Tangerang.

Variabel media sosial marketing melalui Instagram terdapat mean terendah yaitu 2,44 pada sub variabel costumer enggament mengenai pengunjung yang memberikan ulasan pada The Bunker Café. Hal ini dapat ditingkatkan, maka disarankan kepada pihak The Bunker Café untuk menarik minat pengunjung untuk memberi ulasan, seperti memberikan reward atau hadiah oleh pihak The Bunker Café bagi pengunjung yang memberikan ulasan di media sosial marketing Instagram.

Variabel brand image terdapat mean terendah yaitu 3,13 pada sub variabel product attribute. Diharapkan bagi pihak The Bunker Café untuk dapat mempertimbangkan harga yang diberikan kepada konsumen, seperti memberikan diskon, ataupun memberi promo menarik sehingga konsumen merasa senang dan diuntungkan dengan kondisi tersebut.

Penggunaan media sosial marketing Instagram memiliki dampak yang dalam pembentukan brand image. Agar strategi tersebut menghasilkan pengaruh positif yang maksimal maka diperlukan adanya pemilihan konten, baik berbentuk video, gambar maupun tulisan, yang semuanya dikemas secara menarik serta mudah dipahami oleh para pengguna Instagram. Disarankan kepada pemilik The Bunker Café untuk tetap mempertahankan dan meningkatkan konten media sosial marketing Instagram $@$ thebunkercafe agar menjadi lebih menarik lagi.

\section{DAFTAR PUSTAKA}

Fitriana, R., Amrullah, A., \& Suryani, I. (2020). The Impact of Beauty Bloggers' Online Review towards Shopping Tour Interest of Cosmetic Products in Jakarta. TRJ (Tourism Research Journal), 4(1), 12 - 24. doi:10.30647/trj.v4i1.67

Gunelius, Susan. (2011). “30-Minute Social Media Marketing”. United States (US): McGraw-Hill Companies 


\section{JURNAL \\ ANALISIS, PREDIKSI, DAN INFORMASI}

Hans, Willems. (2011). "Transitioning into a Blueconomy". White Paper CustomerDriven Online Engagement, p 1-18

Hennig-Thurau, Thorsten, et al. (2004). Electronic Word-of-Mouth Via ConsumerOpinion Platforms: What Motivates Consumers to Articulate Themselves on the Internet?". Journal of Interactive Marketing Volume 18, Issue 1, 2004, Pages 38 52

Hsieh, MH., Pan, SL, Setiono, R. (2004). "Product-, Corporate-, and Country-Image Dimensions and Purchase Behavior: A Multicountry Analysis". Journal of the Academy of Marketing Science. Volume 32, No. 3, pages251-270. DOI:10.1177/0092070304264262

Kaplan ,Andreas M \&, Haenlein, Michael (2010). "Users of the World, Unite! The Challenges and Opportunities of Social Media". Business Horizons 53. (1). p. 61.

Kim, Angella J and Ko, Eunju. (2011). "Do Social Media Marketing Activities Enhance Customer Equity?”. An Empirical Study of Luxury Fashion Brand.” Journal of Business Research. doi.10.1016/j.jbusres.2011.10.014

Kotler, Phillip, et al. (2016). "Marketing 4.0: Moving from Traditional to Digital". New Jersey: John Wiley \& Sons, Ltd

Kotler dan Keller. (2012). "Manajemen Pemasaran”. Edisi 12. Jakarta: Erlangga

Kotler dan Keller. (2009). “Manajemen Pemasaran”. Jilid I. Edisi ke 13 Jakarta: Erlangga.

Lesmana, Aditya. (2012) Analisis Pengaruh Media Sosial Tweeter terhadap Pembentukan Band Attachment. Universitas Indonesia: Jakarta.

Mangold, WG. and Faulds, DJ. (2009). "Social Media: The New Hybrid Elementof The Promotion Mix". Article Business Horizons

DOI:10.1016/j.bushor.2009.03.002

Ratri, Lutiary Eka. (2007). "Hubungan Antara Citra Merek (Brand Image) Operator Seluler dengan Loyalitas Merek (Brand Loyalty) pada Mahasiswa Pengguna Telepon Seluler di Fakultas Ekonomi Reguler Universitas Diponegoro Semarang". Skripsi. Fakultas Psikologi Universitas Diponegoro.

Salvatore, Dominick. (2005). "Ekonomi Manajerial Buku 2". Jakarta: Salemba Empat.

Shojaee, S. and Azman, A. B. (2013). "An evaluation of Factors Affecting Brand Awareness in the Context of Social Media in Malaysia." Asian Social Science. 9 (17), pp. 72-78.

Sugiyono. (2017). Metode Penelitian Kuantitatif, Kualitatif, dan R\&D. Bandung: Alfabeta

Wijaya, P.S.M., (2008), "Pengaruh Citra Merek Terhadap Loyalitas Konsumen Starbucks Coffee di Yogyakarta”, Jurnal Riset Manajemen \& Bisnis,Vol. 3. No.2, (Juni), 